\section{La normalización sindical entre \\ la dictadura y los comienzos de \\ la democracia (1979-1984)}

Carla Sangrilli
Carla Sangrilli es Becaria de Perfeccionamiento de la Universidad Nacional de Mar del Plata y miembro del Grupo de Investigación «Actores y poder. Argentina siglo XX», de esa universidad.

e-mail: carlasangrilli@hotmail.com

\section{Resumen}

El presente constituye un trabajo exploratorio a partir del cual se propone observar las iniciativas para la normalización sindical de la dictadura y del gobierno de Alfonsín, como así también algunas reacciones del sindicalismo frente a ellas. Se pretende echar luz sobre este proceso que aún no ha merecido la suficiente atención, quizá por la confusión inherente a la precariedad tanto del status jurídico de las organizaciones como de sus propias direcciones.

El artículo se estructura en torno a dos ejes. El primer aspecto abordado se inicia con la sanción en 1979 de la ley 22.105 de Asociaciones Gremiales, que suscitó fuertes repercusiones en el actor sindical y que promovió el reordenamiento de esas entidades. Este se llevó a cabo recién en 1982, cuando el gobierno militar decidió emprender la reorganización de aquellas que estaban intervenidas. La segunda cuestión que se trata es el proyecto alfonsinista de democratizar las organizaciones sindicales conocido como "Ley Mucci», la abierta confrontación gremial que provocó, su rechazo, y cómo, finalmente, se establecieron las bases para llevar adelante el proceso de elecciones en los sindicatos.

\section{Summary}

The present paper is an exploratory work. It proposes to observe the initiatives for the trade-union normalization of the dictatorship and of Alfonsín's government. It also pretends to observe some reactions of the syndicalism regard to them. In this way, the work focuses on a process that has not deserved yet the sufficient attention probably for the inherent confusion of the precariousness of the juridical status of the organizations as well as of their own directions.

The article is constructed concerning two axes. The first issue begins with the enactment of Trade-union Associations Law ( $\left.\mathrm{N}^{0} 22.105\right)$ in 1979, which aroused strong repercussions in the syndicalist actors and promoted the reclassification of these entities. This was not carried out until 1982, when the military government decided to undertake the reorganization of those associations that were intervened. The second issue involved the Alfonsin's project of democratizing the union organizations, known as "Mucci Law», and the opened trade-union confrontation that it provoked, its rejection, and how, finally, laid the groundwork to carry out the election process in unions. 